\title{
Additional evidence for the existence of a precursor molecule of the prothrombin complex in oral anticoagulation
}

Citation for published version (APA):

Veltkamp, J. J., Muis, H., Muller, A. D., Hemker, H. C., \& Loeliger, E. A. (1971). Additional evidence for the existence of a precursor molecule of the prothrombin complex in oral anticoagulation. Thrombosis et diathesis haemorrhagica, 25(2), 312-315. https://doi.org/10.1055/S-0038-1654305

Document status and date:

Published: 30/06/1971

DOI:

10.1055/S-0038-1654305

Document Version:

Other version

Please check the document version of this publication:

- A submitted manuscript is the version of the article upon submission and before peer-review. There can be important differences between the submitted version and the official published version of record.

People interested in the research are advised to contact the author for the final version of the publication, or visit the DOI to the publisher's website.

- The final author version and the galley proof are versions of the publication after peer review.

- The final published version features the final layout of the paper including the volume, issue and page numbers.

Link to publication

\footnotetext{
General rights rights.

- You may freely distribute the URL identifying the publication in the public portal. please follow below link for the End User Agreement:

www.umlib.nl/taverne-license

Take down policy

If you believe that this document breaches copyright please contact us at:

repository@maastrichtuniversity.nl

providing details and we will investigate your claim.
}

Copyright and moral rights for the publications made accessible in the public portal are retained by the authors and/or other copyright owners and it is a condition of accessing publications that users recognise and abide by the legal requirements associated with these

- Users may download and print one copy of any publication from the public portal for the purpose of private study or research.

- You may not further distribute the material or use it for any profit-making activity or commercial gain

If the publication is distributed under the terms of Article 25fa of the Dutch Copyright Act, indicated by the "Taverne" license above, 


\section{THROMBOSIS ET DIATHESIS HAEMORRHAGICA}

EDITORES: K. M. BRINKHOUS, CHAPEL HILL; E. DEUTSCH, WIEN; R. GROSS, KÖLN; J. E. JORPES, STOCKHOLM; F. KOLLER, BASEL; J. ROSKAM, LIËGE; SOL SHERRY, PHILADELPHIA; J.-P. SOULIER, PARIS; I. S. WRIGHT, NEW YORK

\section{Additional Evidence for the Existence of a Precursor Molecule of the Prothrombin Complex in Oral Anticoagulation}

J. J. Veltkamp, H. Muis, A. D. Muller, H. C. Hemker and E. A. Loeliger

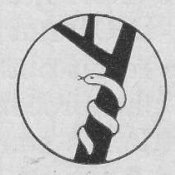

F. K. SCHATTAUER VERLAG - STUTTGART-NEW YORK 
In vitamin $\mathrm{K}$ deficiency or intake of oral anticoagulants (vitamin $\mathrm{K}$-antagonists) the synthesis of the blood clotting factors of the prothrombin complex is blocked in one of its last steps. Polypeptide chain synthesis on the ribosomal level (7) is not hampered, and the demonstration of precursor products, which hypothetically could resemble the clotting factors, has been attempted in several investigations $(2,3,5,8)$. Immunochemical methods enabled Ganrot and Niléhn (2) to demonstrate two populations of prothrombin molecules in coumarin plasma, and Josso et al. (8) found an excess of immunologically demonstrable prothrombin over prothrombin activity. The present report concerns the demonstration of a precursor molecule that resembles factor IX in its antigenic properties.

\section{Methods}

Factor IX (PTC) assays were carried out with a one-stage kaolin-phospholipid activated principle (14). Clotting times were read automatically with coagulometers (DEPEX, de Bilt, The Netherlands). The PTC-inhibitor plasma was kindly supplied by Dr. Harold Roberts of Chapel Hill. The inhibitor plasma was received on 27 July 1969 and stored at $-80^{\circ} \mathrm{C}$. It was used in a dilution of $1: 2$ in the method for measuring PTC-inhibitor neutralizing capacity as described by Roberts et al. $(1,12)$. The titre of the inhibitor did not alter during more than a year of storage.

\section{Results}

In Table 1 it can be seen that a coumarin plasma, in this ease obtained from a patient (No.7) with virtually no factor IX activity in the plasma due to suicidal intake of the long-acting coumarin-congener phenprocoumon, contains a large amount of PTCinhibitor neutralizing material. This particular plasma also had less than $1 \%$ factor II, VII, and X activity. Another patient (No. 8), with 8.5\% factor IX activity (Thrombotest $300 \mathrm{sec}$ due to overdosage of phenprocoumon), showed $22 \%$ PTC-INC (PTC Inhibitor Neutralizing Capacity). $\mathrm{BaSO}_{4}$ adsorption removes not only "clottable" factor IX (No.11) but also PTC-INC (No.10) from oxalated plasma. Al(OH) ${ }_{3}$ has the same action on citrated plasma. PTC-INC is not mimicked by the presence of phenprocoumon, as can be judged from the result obtained with plasma No.12, which was composed of sample No. 6 to which phenprocoumon was added in vitro in a concentration of $10 \mu \mathrm{g} / \mathrm{ml}$. This concentration is comparable to the concentration of the coumarin-congener in samples 7 and 8 (about $7 \mu \mathrm{g} / \mathrm{ml}$ ), assayed according to Seiler and Duckert (13).

Thrombos. Diathes. haemorrh. (Stuttg.) 
Table 1. PTC-inhibitor neutralizing capacity (PTC-INC) of various plasma samples.

\begin{tabular}{|c|c|c|c|c|c|}
\hline Material & $\begin{array}{c}\text { Factor IX } \\
\text { activity } \\
(\%)\end{array}$ & $\begin{array}{r}\text { Expected } \\
\text { PTC-INC } \\
\text { (residual } \\
\text { activity }\end{array}$ & $\begin{array}{l}\text { Observed } \\
\text { PTC-INC } \\
\text { actor IX } \\
\text { in \%) }\end{array}$ & $\begin{array}{l}\text { Number } \\
\text { of assays }\end{array}$ & $\begin{array}{c}\text { More } \\
\text { PTC-INC } \\
\text { than } \\
\text { factor IX } \\
\text { activity }\end{array}$ \\
\hline 1. Normal plasma & 100 & $\leq 55$ & 47 & 6 & - \\
\hline 2. Diluted normal plasma & 50 & $\leq 27.5$ & 22.5 & 5 & - \\
\hline 3. Diluted normal plasma & 25 & $\leq 13.75$ & 9 & 2 & - \\
\hline 4. Buffer & 0 & $<5$ & $<5$ & 3 & - \\
\hline 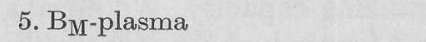 & $<1$ & $25-60$ & 31 & 2 & + \\
\hline 6. B-plasma & $<1$ & 1) & $<5$ & 4 & - \\
\hline 7. Coumarin plasma & $<1$ & 1) & 20 & 3 & + \\
\hline 8. Coumarin plasma & 8.5 & 1) & 22 & 1 & + \\
\hline $\begin{array}{l}\text { 9. Citrated coumarin plasma } \\
\mathrm{Al}(\mathrm{OH})_{3} \text { adsorbed }\end{array}$ & $<1$ & 1) & $<5$ & 1 & - \\
\hline $\begin{array}{l}\text { 10. Oxalated coumarin plasma } \\
\mathrm{BaSO}_{4} \text { adsorbed }\end{array}$ & $<1$ & 1) & $<5$ & 1 & - \\
\hline $\begin{array}{l}\text { 11. Normal oxalated plasma } \\
\mathrm{BaSO}_{4} \text { adsorbed }\end{array}$ & $<1$ & $<5$ & $<5$ & 1 & - \\
\hline 12. B-plasma + phenprocoumon & $<1$ & 1) & $<5$ & 1 & - \\
\hline
\end{tabular}

1) experimental sample.

\section{Discussion}

Oral anticoagulants take effect not only by depressing coagulation factors II, VII, $I X$, and $X$, due to an anti-vitamin-K action, but also cause the appearance of a protein called PIVKA (Protein Induced by Vitamin $K A$ bsence) (5). In prothrombin time methods using thromboplastins prepared from brain from various species (9), this protein exerts a competitive inhibitory effect. The site of inhibition in the reaction sequence of coagulation has been localized at the conversion of factor $\mathrm{X}$ from a proenzyme into an active moiety (4).

It is thought that the protein in question is a precursor of one or more of the coagulation factors of the prothrombin complex. During the blockade of the vitamin-Kdependent step assumed to be responsible for conversion of the precursor into a coagulation factor (II, VII, IX, or X), synthesis of the precursor in hepatic cells leads to overflow of the precursor into the circulation. On the basis of this hypothesis coagulation-factor like protein could be expected to circulate in vitamin-K-deficiency or oral anticoagulation. In attempting to further define the precursor, Ganrot and Niléhn (2) demonstrated a prothrombin in coumarin plasma with a electrophoretic mobility differing from the normal. They also reported defective adsorption of PIVKA onto $\mathrm{BaSO}_{4}$, but this finding seems doubtful, because they used citrated plasma and adsorbed with $10 \mathrm{mg} \mathrm{BaSO}_{4} / \mathrm{ml}$. Under these conditions, the adsorption of both the prothrombin complex and PIVKA is known to be incomplete.

Another indication of the presence of a prothrombin-like material in anticoagulated human plasma is the finding of material that develops thrombin activity at a rate much more slowly than prothrombin itself (6). Investigations by both Prentice (10) and Prydz (11) clearly demonstrated an excess of immunologically detectable factor X over factor $\mathrm{X}$ activity in anticoagulated samples. 
The investigation reported here shows that a significant amount of PTC-inhibitor neutralizing material can be demonstrated in anticoagulated human plasma. The few selected samples used in this study contain very low factor IX activity and thus enabled us to make economic use of the PTC-inhibitor. Higher levels of factor IX activity make the interpretation of the difference from the residual factor IX activity reflecting the amount of PTC-inhibitor neutralizing material progressively more difficult (and therefore create a statistical problem).

The existence of protein induced by vitamin $\mathrm{K}$ absence or antagonist has been demonstrated in different ways: as an inhibitor of prothrombin time type estimation, as an abnormal prothrombin, as anti-factor-II cross-reacting material, as antifactor- $\mathrm{X}$ cross-reacting material, and, now as PTC-inhibitor neutralizing capacity. We do not as yet want to assume the existence of a different precursor for each of the vitamin $\mathrm{K}$ dependent coagulation factors, because the activities mentioned might all be due to a single type of molecule. The possibility that more than one type of PIVKA exists must be taken into consideration.

\section{Summary}

By means of the PTC-inhibitor neutralizing test (12) a significant excess of PTC (factor IX)-like material over factor IX activity could be demonstrated in human coumarin plasma. This cross-reacting material is considered to be a precursor of one or all of the clotting factors of the prothrombin complex.

\section{Résumé}

A l'aide du test de neutralisation du PTC (12) on met en évidence, dans le plasma d'individus traités aux dérivés de la coumarine, un excès marqué de matériel semblable au PTC (facteur IX) par rapport au facteur IX procoagulant. Ce matériel interférant est considéré comme étant un précurseur d'un ou de tous les facteurs du complexe de la prothrombine.

\section{Zusammenfassung}

Mit Hilfe des PTC-Inhibitorneutralisationstestes (12) konnte im menschlichen Coumarin-Plasma ein signifikanter Überschuß an PTC-(Faktor IX)-ähnlichem Material gegenüber der Gerinnungsfaktor-IX-Aktivität nachgewiesen werden. Es wird angenommen, daß dieses kreuzreagierende Material eine Vorstufe eines oder aller Gerinnungsfaktoren des Prothrombinkomplexes ist.

\section{References}

(1) Brown, P.E., C. Hougie, H. R. Roberts: The genetic heterogeneity of hemophilia B. New Engl. J. Med. 283: 61-62 (1970).

(2) Ganrot, P.O., J.E. Niléhn: Plasma prothrombin during treatment with dicumarol II: Demonstration of an abnormal prothrombin fraction. Scand. J. clin. Lab. Invest. 22: 23 (1968).

(3) Hemker, H.C., J.J. Veltkamp, A. Hensen, E. A. Loeliger: Nature of prothrombin biosynthesis: Preprothrombinaemia in vitamin K-deficiency. Nature (Lond.) 200: 589 (1963).

(4) Hemker, H. C., A. D. Muller: Kinetic aspects of the interaction of blood clotting enzymes V. The reaction mechanism of the extrinsic coagulation system as revealed by the kinetics of onestage estimations of coagulation enzymes. Thrombos. Diathes. haemorrh. (Stuttg.) 19: 368 (1968). 
(5) Hemker, H. V., J. J. Veltkamp, E. A. Loeliger: Kinetic aspects of the interaction of blood enzymes, III. The reaction mechanism of the extrinsic clotting system as revealed by the kinetics of one-stage estimations of coagulation enzymes. Thrombos. Diathes. haemorrh. (Stuttg.) 19: 346 (1968).

(6) Hemker, H.C., A. D. Muller, E. A. Loeliger: Preliminary reports: Two types of prothrombin in vitamin K-deficiency. Thrombos. Diathes. haemorrh. (Stuttg.) 23: 633-638 (1970).

(7) Hill, R. B., S. Gaetani, A. M. Paolucci, P. B. RamaRao, R. Alden, G. S. Ranhotra: Vitamin K and biosynthesis of protein and prothrombin. J. biol. Chem. 243: 3930 (1968).

(8) Josso, F., J. M. Lavergne, M. Gouault, O. Prou-Wartelle, J. P. Soulier: Differents états moleculaires du facteur II (prothrombine). Leur étude à l'aide de la staphylocoagulase et d'anticorps anti-facteur II. I. Le facteur II chez les sujets traités par les antagonistes de la vitamine K. Thrombos. Diathes. haemorrh. (Stuttg.) 20:88 (1968).

(9) Loeliger, E. A., J. B. Meeuwisse-Braun, H. Muis, F. J. J. Buytendijk, J. J. Veltkamp, H. C. Hemker: Laboratory control of oral anticoagulants: Definition of therapeutic range in terms of different thromboplastin preparations. Thrombos. Diathes. haemorrh. (Stuttg.) 23: $569(1970)$.

(10) Prentice, C. M.: Panel discussion. The International Society on Thrombosis and Haemostasis. Montreux, Switzerland, July 29 - August 1, 1970.

(11) Prydz, H.: Panel discussion. The International Society on Thrombosis and Haemostasis. Montreux, Switzerland, July 29 - August 1, 1970.

(12) Roberts, H. R., J. E. Grizzle, W. D. McLester et al.: Genetic variants of hemophilia B: detection by means of a specific PTC inhibitor. J. clin. Invest. 47: 360-365 (1968).

(13) Seiler, $K ., F^{\prime}$. Duckert: Properties of 3-(1-phenyl-propyl)-4-oxycoumarin (Marcoumar $\left.{ }^{\circledR}\right)$ in the plasma when tested in normal cases and under the influence of drugs. Thrombos. Diathes. haemorrh. (Stuttg.) 19: 389-397 (1968).

(14) Veltkamp, J.J., F. F. Drion, E. A. Loeliger: Detection of the carrier state in hereditary coagulation disorders. I. Thrombos. Diathes. haemorrh. 19: 279 (1968); II. Thrombos. Diathes. haemorrh. 19: 403 (1968).

Received for Publication 2. 12. 1970 Copyright by F. K. Schattauer Verlag, Stuttgart - Der Verlag behält sich alle Rechte, besonders die des Nachdruckes,
der Vervielfältigung und der Ưbersetzung yor. 